\title{
Reconstruction of the multielement apparatus of the earliest Triassic conodont, Hindeodus parvus, using synchrotron radiation X-ray micro-tomography
}

\author{
Sachiko Agematsu, ${ }^{1}$ Kentaro Uesugi, ${ }^{2}$ Hiroyoshi Sano, ${ }^{3}$ and Katsuo Sashida ${ }^{4}$ \\ ${ }^{1}$ Faculty of Life and Environmental Sciences, University of Tsukuba, Ibaraki 305-8572, Japan 〈agematsu@ geol.tsukuba.ac.jp〉 \\ ${ }^{2}$ Japan Synchrotron Radiation Research Institute (JASRI/SPring-8), Sayo, Hyogo 679-5198, Japan 〈ueken@spring8.or.jp〉 \\ ${ }^{3}$ Department of Earth and Planetary Sciences, Kyushu University, Fukuoka 819-0395, Japan〈sano@geo.kyushu-u.ac.jp〉 \\ ${ }^{4}$ Faculty of Life and Environmental Sciences, University of Tsukuba, Ibaraki 305-8572, Japan 〈sashida@geol.tsukuba.ac.jp〉
}

\begin{abstract}
Earliest Triassic natural conodont assemblages preserved as impressions on bedding planes occur in a claystone of the Hashikadani Formation, which is part of the Mino Terrane, a Jurassic accretionary complex in Japan. In this study, the apparatus of Hindeodus parvus (Kozur and Pjatakova, 1976) is reconstructed using synchrotron radiation micro-tomography $(\mathrm{SR}-\mu \mathrm{CT})$. This species has six kinds of elements disposed in 15 positions forming the conodont apparatus. Carminiscaphate, angulate, and makellate forms are settled in pairs in the $\mathrm{P}_{1}, \mathrm{P}_{2}$, and $\mathrm{M}$ positions, respectively. The single alate element is correlated with the $\mathrm{S}_{0}$ position. The $\mathrm{S}$ array is a cluster of eight ramiforms, subdivided into two inner pairs of digyrate $S_{1-2}$ and two outer pairs of bipennate $S_{3-4}$ elements. The reconstruction is similar to a well-known ozarkodinid apparatus model. In addition, the $\mu \mathrm{CT}$ images show that the 'anterior' and 'posterior' processes of the $S_{1-2}$ elements faced the caudal and rostral ends of the living conodont body, respectively.
\end{abstract}

\section{Introduction}

A conodont natural assemblage is a fossil of its skeletal elements juxtaposed on a bedding plane from which it is possible to discuss the homology of the elements within the conodont apparatus. Knowledge of homology allows deduction of relationships among taxa, and thus improved knowledge of the phylogeny of conodonts. Logical and statistical methods can be applied to taxa for which evidence of natural assemblages or clusters is not available for multielement apparatus reconstructions (e.g., Walliser, 1964; Webers, 1966; Jeppsson, 1971; Dzik, 1991). The apparatus structure of the genus Hindeodus, the subject of this study, is currently poorly understood. This genus has a long stratigraphic range, from the lower Carboniferous (Mississippian) to the lowermost Triassic. When Rexroad and Furnish (1964) first described the morphogenus Hindeodus, they designated Hindeodus imperfectus (= Trichonodella imperfecta Rexroad, 1957) as the type species. This morphospecies, a symmetrical crown-shaped element, was incorporated into the multielement apparatus of Hindeodus cristulus (=Spathognathodus cristulus Youngquist and Miller, 1949) as the Sa element by Sweet (1977). According to Sweet's definition, Hindeodus has a skeletal apparatus comprising six kinds of elements: $\mathrm{Pa}, \mathrm{Pb}, \mathrm{M}, \mathrm{Sa}, \mathrm{Sb}$, and $\mathrm{Sc}$.

The morphological variety of Hindeodus $\mathrm{Pa}$ elements causes them to be generally useful for biostratigraphy, whereas the associated ramiform elements appear to be somewhat difficult to distinguish as separate species. Sweet (1977), who defined multielement Hindeodus, described four species, including H. cristulus and H. typicalis (Sweet, 1970a), and reconstructed four ramiform complexes, consisting of $\mathrm{Pb}, \mathrm{M}$, $\mathrm{Sa}, \mathrm{Sb}$, and $\mathrm{Sc}$ elements, for those species. He described the morphological characters of these ramiform elements and mentioned that it was difficult, at least in part, to assign dissociated specimens to each species. The ramiform complex has often confused the classification of both species and genera. This problem emerged as part of the "HindeodusDiplognathodus Problems" (von Bitter and Merrill, 1985, p. 81). In any case, for discrimination of the element set forming a Hindeodus apparatus, it is necessary to examine closely the stratigraphic co-occurrence and similarities of morphological characters between ramiform and $\mathrm{Pa}$ elements.

In general, the morphological variation of the $\mathrm{Pa}$ element and of the ramiform complex of Hindeodus species was relatively monotonous from the late Carboniferous to the middle Permian (Sweet, 1988; Nicoll et al., 2002). In contrast, during the late Permian to earliest Triassic, Hindeodus evolved rapidly into more than 10 species, the Pa elements of which have been reported in many papers discussing the biostratigraphy of the Permian-Triassic Boundary (PTB) (e.g., Kozur, 1995; Lai et al., 1996; Nicoll et al., 2002). Apparatus reconstruction and description of ramiform complexes have been undertaken mainly for the early Carboniferous species $H$. cristulus and $H$. scitulus (Hinde, 1900), and PTB species including $H$. typicalis, H. julfensis (Sweet in Teichert et al., 1973), H. latidentatus (Kozur, Mostler, and Rahimi-Yazd, 1975), H. parvus 
(Kozur and Pjatakova, 1976), H. changxingensis Wang, 1995, H. postparvus Kozur, 1989, and H. sosioensis Kozur, 1996 (e.g., Sweet, 1977, 1988; von Bitter and Plint-Geberl, 1982; von Bitter and Plint, 1987; Kozur, 1996).

From the cladistic analysis of Donoghue et al. (2008), the genus Hindeodus currently belongs to the superfamily Polygnathacea, suborder Ozarkodinina, order Ozarkodinida. That analysis used the premise that the multielement reconstruction of this genus proposed by Sweet (1977) and others is strongly reliable. In this study, the apparatus of the earliest Triassic conodont $H$. parvus is reconstructed using synchrotron radiation micro-tomography (SR- $\mu \mathrm{CT})$. Our conclusion supports Donoghue and his colleagues' premise and provides a taxonomic framework for the genus.

\section{Materials and methods}

Agematsu et al. (2015) described natural assemblages of $H$. parvus and $H$. typicalis from siliceous claystones of the Hashikadani Formation, which forms part of the Mino Terrane, a Jurassic accretionary complex in central Japan. Their study section (3.8 m thick) consists of uppermost Permian chert and lowermost Triassic black claystone; the latter contains conodonts (Fig. 1). Because all specimens are preserved as impressions and some additional elements may be hidden under the visible molds, the composition of the assemblages cannot be completely observed under binocular or scanning electron microscopes. According to Agematsu et al. (2015), the assemblages of both species comprise at most 13 elements, including pairs of $\mathrm{P}_{1}, \mathrm{P}_{2}$, and $\mathrm{M}$ elements, as well as a single $\mathrm{S}_{0}$ element with two digyrate and four bipennate elements making up the $S$ array. A pair of $S_{1}$ elements was not recognized. In this study, the multielement apparatus of $H$. parvus is reconstructed using $\mathrm{SR}-\mu \mathrm{CT}$.

$\mathrm{SR}-\mu \mathrm{CT}$ measurements were performed at experimental hutch 1 of BL20B2 in the synchrotron radiation facility, SPring8, Hyogo, Japan (Goto et al., 2001). Claystone samples containing natural conodont assemblages were cut into small pieces $\sim 10-20 \mathrm{~mm}$ high, $5-10 \mathrm{~mm}$ wide, and $2-5 \mathrm{~mm}$ thick. The measurement conditions of the mirco-tomography were as follows: X-ray energy was $15-35 \mathrm{keV}$; number of projections was 1800 for 180 degrees; exposure time for one projection was 200 msec; total scan time of one CT measurement was $\sim 8$ minutes; effective pixel size was $2.76 \mu \mathrm{m}$; distance from the sample to detector was set to $70 \mathrm{~mm}$.

The CT reconstruction was done with convolution back projection method (Uesugi et al., 2010) after phase retrieval (Paganin et al., 2002). Three-dimensional images were built from the stacked 2D images with volume rendering using the open-source visualization software Drishti (Limaye, 2012).

Nineteen samples were analyzed, of which two yielded well-preserved fossil images. Figure 2 illustrates specimens of the ventral and dorsal parts of the assemblage, which originally constituted one natural assemblage. The images include the claystone-air interface and distinctly show the outline of each element. This fossil was recovered from a horizon $40 \mathrm{~cm}$ above the base of the claystone strata, which is correlated with the lower Induan (Sano et al., 2010).
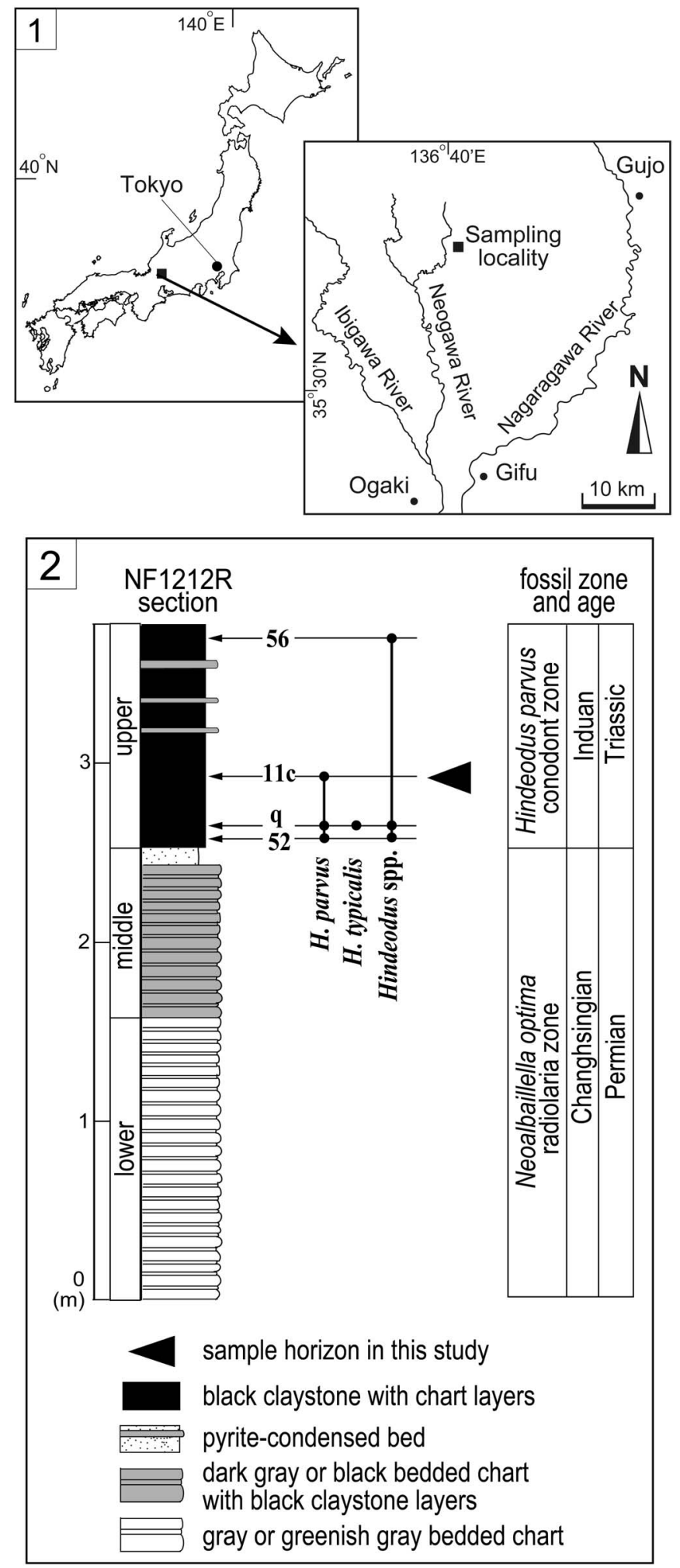

Figure 1. Locality and horizon of the conodont natural assemblage: (1) locality map of the study section; (2) lithologic column of the study section indicating the sample horizon.

Repository and institutional abbreviation.-Two specimens described herein are deposited at the Doctoral Program in Earth Evolution Sciences, University of Tsukuba, Japan, with the prefix EESUT. 


\section{Systematic paleontology}

Order Ozarkodinida Dzik, 1976

Suborder Ozarkodinina, Dzik, 1976

Superfamily Polygnathacea Bassler, 1925

Genus Hindeodus Rexroad and Furnish, 1964

Type species.-Spathognathodus cristulus Youngquist and Miller, 1949, from the Mississippian of south-central Iowa, USA, by original designation.

Hindeodus parvus (Kozur and Pjatakova, 1976)

Figures 2.1, 2.2, 3.1, 3.2

Multielement

1975 Anchignathodus parvus; Kozur, p. 7, pl. 1, figs. 17, 22 $\left(\mathrm{P}_{1}\right), 21\left(\mathrm{~S}_{3-4}\right)$.
1976 Anchignathodus parvus Kozur and Pjatakova, p. 123, pl. 1, figs. a, b, e $\left(\mathrm{P}_{1}\right), \mathrm{h}\left(\mathrm{S}_{3-4}\right)$.

1995 Hindeodus parvus; Kozur, p. 69, pl. 2, figs. 4, 6, 9, 13 $\left(\mathrm{P}_{1}\right)$, pl. 3, figs. 1-4 $\left(\mathrm{P}_{1}\right), 5(\mathrm{M}), 6\left(\mathrm{~S}_{1-2}\right), 7(\mathrm{P} 2), 8\left(\mathrm{~S}_{3-4}\right)$.

1995 Hindeodus parvus; Kozur et al., p. 206, pl. 1, figs. a, b, g $\left(\mathrm{P}_{1}\right)$, e $\left(\mathrm{S}_{1-2}\right)$.

1996 Hindeodus parvus; Kozur, p. 94, pl. II, figs. 5, 6, 7, 8 $\left(\mathrm{P}_{1}\right)$, pl. III, figs. 1-3, 9, $11\left(\mathrm{P}_{1}\right), 4\left(\mathrm{~S}_{0}\right), 5(\mathrm{M}), 6,10$ $\left(\mathrm{S}_{1-2}\right), 7\left(\mathrm{P}_{2}\right), 8\left(\mathrm{~S}_{3-4}\right)$, pl. IV, figs. 5, 6, $7\left(\mathrm{P}_{1}\right)$.

2015 Hindeodus parvus; Agematsu et al., p. 1285, figs. 2-4.

Holotype.-Carminiscaphate form from the lowermost Triassic of Achura, Azerbaijan (Kozur and Pjatakova, 1976, pl. 1, fig. b).

Description.-Natural assemblage consists of ventral and dorsal specimens. The former contains 14 elements: sinistral-dextral
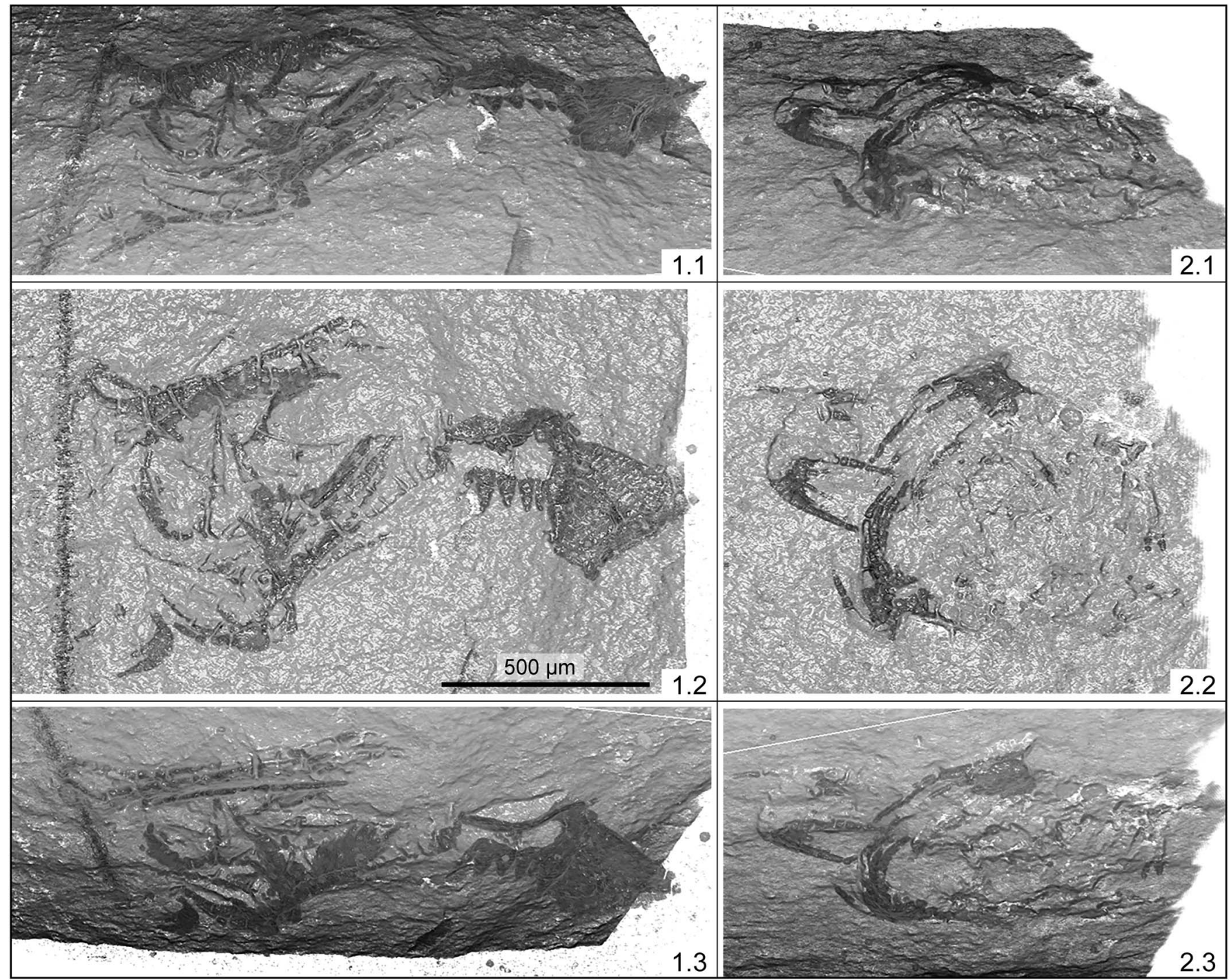

Ventral specimen in ventral view

Dorsal specimen in dorsal view

Figure 2. Three-dimensional images of the natural assemblage of Hindeodus parvus (Kozur and Pjatakova, 1976) from the horizon 11C of the NF1212R section, the upper part of the Hashikadani Formation: (1.1-1.3) ventral view of the ventral specimen (EESUT-ag0005); (2.1-2.3) dorsal view of the dorsal specimen (EESUT-ag0006). Scale bar indicates $500 \mu \mathrm{m}$. 

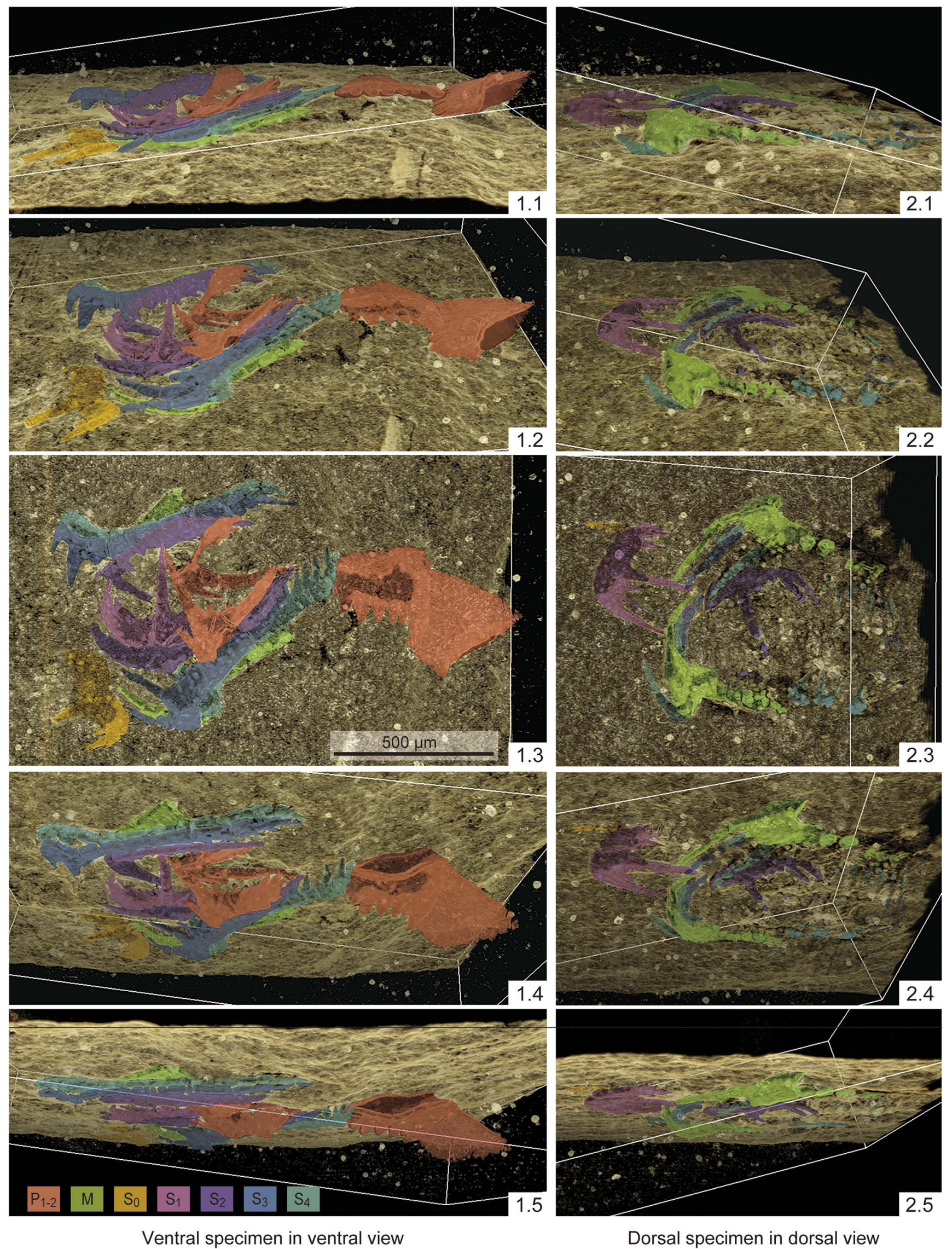

Figure 3. Colored pictures of $H$. parvus: (1.1-1.5) ventral view of the ventral specimen (EESUT-ag0005); (2.1-2.5) dorsal view of the dorsal specimen (EESUT-ag0006). Scale bar indicates $500 \mu \mathrm{m}$. 
pairs of $P_{1}, P_{2}, S_{2}, S_{3}$, and $S_{4}$; single $S_{0}$; dextral $S_{1}$; and parts of paired $\mathrm{M}$ elements. The latter mainly comprises a ramiform cluster, including sinistral-dextral pair of $\mathrm{M}$, sinistral $\mathrm{S}_{1}$, and parts of $S_{2}, S_{3}$, and $S_{4}$ elements.

Carminiscaphate $\mathrm{P}_{1}$ bears the largest distal denticle on an 'anterior' process. That denticle is twice as high as the other five, accompanied by accessory node on 'posterior' end of unit. Basal cavity expands 'laterally,' occupying 'posterior' two-thirds of element. $\mathrm{P}_{2}$ angulate, with long robust cusp and short 'anterior' process bearing large denticle. Relatively long 'posterior' process carrying at least a number of short denticles twists distally; its 'inner' surface faces medial side. Small basal cavity opens under cusp. Makellate M with long slender cusp, very short 'inner lateral' process, and denticulate 'outer lateral' process with relatively long denticle adjoining cusp. Unit bends sharply 'posteriorly' just 'outside' cusp.

$\mathrm{S}_{0}$ symmetrical alate lacking 'posterior' process; both 'lateral' processes high and short. Digyrate elements in $\mathrm{S}_{1-2}$ positions possess long robust cusp and denticulate 'inner' and 'outer lateral' processes, although distal parts of 'outer lateral' processes of both $\mathrm{S}_{1}$ elements not preserved in this material. 'Inner lateral' process higher and shorter than 'outer lateral' one; the latter twists at joint and its 'posterior' surface turns 'upward'. Bipennate elements in $\mathrm{S}_{3-4}$ positions characterized by long slender cusp, denticulate long 'posterior' process, and short 'anterior' process bearing relatively long 'antero-terminal' denticle.

Materials.-Two clusters constituting one natural assemblage: EESUT-ag0005, 0006.

Remarks.-On the basis of the morphology of the $\mathrm{P}_{1}$ and $\mathrm{S}_{1-2}$ elements, the specimens are identified as H. parvus. According to Kozur (1996), the $S_{1-2}$ element of this species is distinguished from those of $H$. typicalis and $H$. latidentatus (Kozur, Mostler, and Rahimi-Yazd, 1975) by the bending position of the unit: the $S_{1-2}$ elements of the latter two species bend 'posteriorly' just 'outside' a cusp; in contrast, those of $H$. parvus bend 'posteriorly' just 'inside' a cusp. Because both the sinistral and dextral $\mathrm{S}_{1}$ elements in the present specimens are broken just 'inside' the cusp, these cracks indicate the bending position. This feature of the $\mathrm{S}_{1-2}$ elements is consistent with $H$. parvus.

\section{Results and discussion}

Natural assemblage of Hindeodus parvus.-The SR- $\mu \mathrm{CT}$ images clearly show that an apparatus of $H$. parvus is composed of 15 elements settled in sinistral-dextral pairs in the $\mathrm{P}_{1}, \mathrm{P}_{2}, \mathrm{M}, \mathrm{S}_{1}$, $S_{2}, S_{3}$, and $S_{4}$ positions and a single $S_{0}$ position probably on the median plane (Figs. 3, 4; Supplemental Data 1). The element structure is in agreement with the definition of Hindeodus by Sweet (1977). The SR- $\mu$ CT images also clarify the threedimensional microarchitecture of the natural assemblage in terms of the general location and direction of elements in the apparatus.

A crown-shaped alate element without a 'posterior' process, the $S_{0}$ element, lies on the rostralmost side of the specimens. The element has the 'upper' side turned rostrally and the 'anterior' surface ventrally. It is probable that the element is on the median plane and its 'anterior' surface was oriented in the ventral or rostral direction in the living conodont body.
The central parts of the specimens are made up of ramiform clusters, consisting of juxtaposed elements in the $S_{1}-S_{4}$ and $M$ positions. The so-called $\mathrm{S}$ array, which is the main part of the ramiform cluster, comprises two pairs of digyrate $S_{1-2}$ elements on the inside and two pairs of bipennate $S_{3-4}$ on the outside. Although a sinistral $S_{1}$ element is out of place, the 'inner lateral' and 'outer lateral' processes of the other digyrate elements point to the rostral and caudal directions of the apparatus, respectively. Their 'posterior' surfaces face ventrally. The bipennate elements have their cusp and a terminal denticle on an 'anterior' process pointing in the rostro-inner direction, and with a 'posterior' process extending caudally. The 'inner' surfaces of these elements are turned to the ventral side of the specimen. Two makellate elements, located in the M positions, lie on the dorso-sinistral and -dextral sides of the $\mathrm{S}$ array with cusps pointing to the rostro-inner side and the 'outer lateral' process at the caudal side. The 'posterior' side faces ventrally. It is quite likely that the 'outer lateral' processes of the $\mathrm{S}_{1-2}$ and $\mathrm{M}$ elements and the 'posterior' ones of the $S_{3-4}$ elements were arranged approximately parallel to the rostro-caudal axis in the living conodont body. In addition, all elements in the ramiform clusters seem to have their concave surfaces directed ventrally or inwardly as a whole.

A pair of angulate elements in the $\mathrm{P}_{2}$ position is placed between the caudal half of the sinistral and dextral $\mathrm{S}$ arrays. The 'inner' sides face ventrally. The 'upper' or 'inner lateral' surfaces appear to be opposite each other across the median plane. In the caudalmost part, there are $\mathrm{P}_{1}$ positions in which two carminiscaphate elements are disposed. Although the posture of the $\mathrm{P}_{1}$ elements in the living conodont body is unclear, the 'upper' surfaces at least appear to face each other.

This arrangement and direction of elements is also supported by the natural-assemblage specimens analyzed by Agematsu et al. (2015). This reconstruction is nearly identical to a well-known apparatus model of ozarkodinids including 4P-2M-9S elements (Purnell and Donoghue, 1997; Purnell et al., 2000).

Terms for orientation of $S_{1-2}$ elements.-Elements disposed in the $\mathrm{S}_{1-2}$ and $\mathrm{S}_{3-4}$ positions have been labeled $\mathrm{Sb}$ and $\mathrm{Sc}$, respectively, in previous studies. Sweet (1988) stated that the $\mathrm{Sb}$ element was the most diagnostic feature of the Hindeodus apparatus. According to Kozur (1996), the morphological differences of some Hindeodus Sb elements are sufficient to help with identification of species. However, the terms for orientation of the digyrate elements have been confused, and thus need to be summarized here.

Most papers reporting Hindeodus $\mathrm{S}_{1-2}$ elements and their equivalents have described the two processes of the element as the 'anterior' and 'posterior' ones, whereas Sweet (1977) defined the $\mathrm{Sb}$ element as a digyrate form with two 'lateral' processes. The present study follows the usage of Sweet and describes these processes as 'lateral.' An additional problem is that many previous studies have stated that the $S_{1-2}$ elements of Hindeodus are characterized by an 'upwardly' bent process (e.g., Sweet, 1988). This character is sometimes difficult to discriminate. The LE element of Ellisonia teicherti Sweet, 1970a, which is included in some Hindeodus species as part of the ramiform complexes, is equivalent to the $S_{1-2}$ elements. 


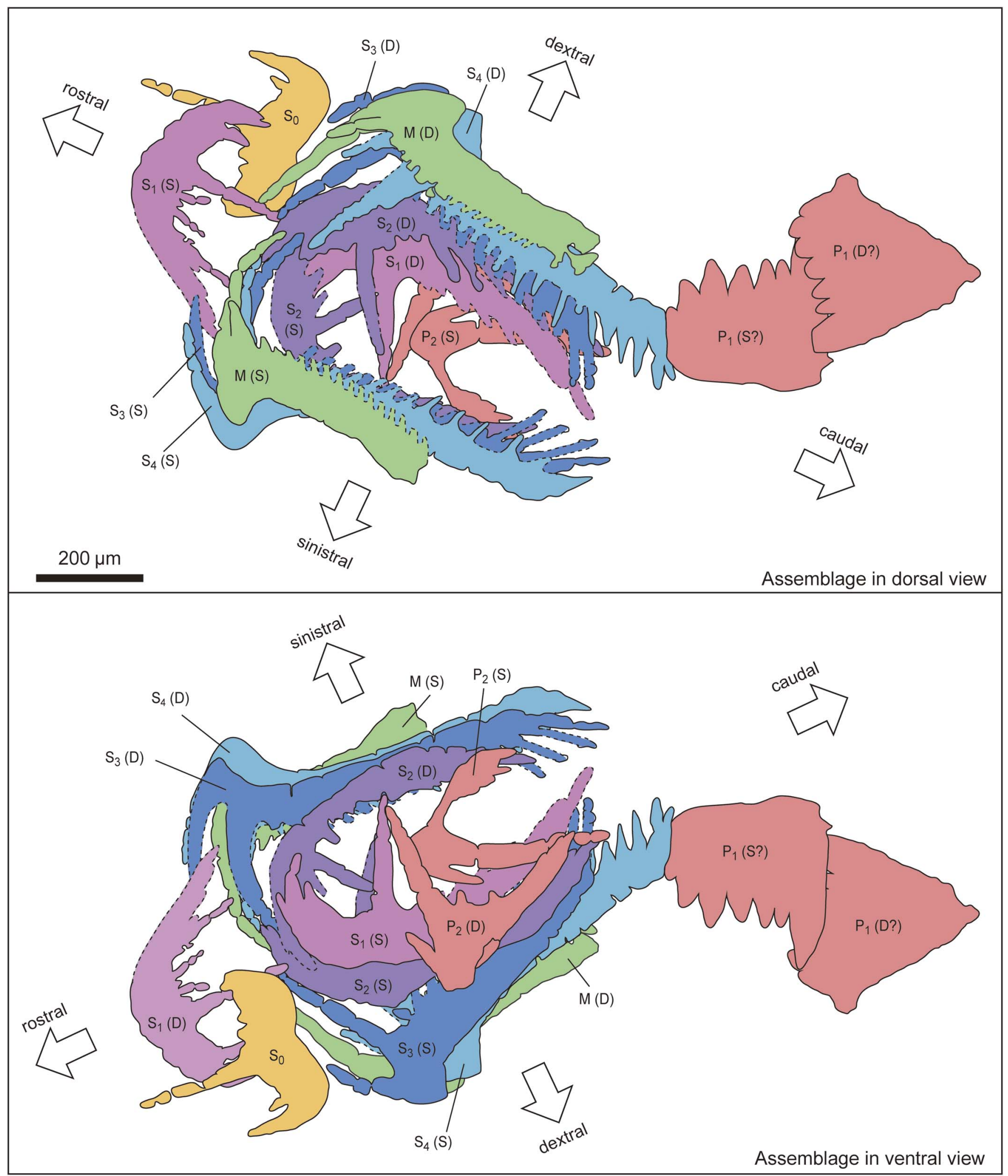

Figure 4. Drawings of the reconstructed assemblage based on the ventral and dorsal specimens. The upper one represents the dorsal view of the assemblage and the lower represents the ventral view. The rostral and caudal sides mean that these are nearer head and tail ends of a conodont body, respectively.

Sweet (1970b) described that an 'anterior' process of the LE element "projected laterally and upward" (Sweet, 1970b, p. 233). This element is homologous with the Pl element of Ellisonia teicherti?, which was described by von Bitter (1972), and the $\mathrm{A}_{2}$ element of Ozarkodina minuta (Ellison, 1941) (= Hindeodus minutus) of Baesemann (1973). The Pl element is characterized 
by "an anterior bar that is directed sharply upward" (von Bitter, 1972 , p. 71), whereas the $A_{2}$ element possesses a 'posterior' process with "upswept posterior end" (Baesemann, 1973, p. 706). Matsuda (1981), however, gives the clearest explanation for the morphology of the Sb element. According to him, the 'anterior' process of the element bends 'inward' around a cusp and the 'inner' surface of the 'anterior' process faces slightly 'upward' as a result of twisting at the bend. It seems that all previously illustrated $\mathrm{S}_{1-2}$ elements of Hindeodus possess a process with a similar bend and twist. The present study describes the bent and twisted process of a digyrate element as an 'outer lateral' process. That is, the $S_{1-2}$ element bears two 'lateral' processes and bends around the cusp; the 'outer lateral' process twists at the bend and turns its 'posterior' surface 'upward.' The 'outer lateral' process, which can be compared with the 'anterior' processes or bars of Sweet (1970b), von Bitter (1972), Matsuda (1981), and Kozur (1996), and the 'posterior' process of Baesemann (1973), extends caudally in the conodont apparatus.

\section{Conclusions}

Although previous multielement reconstructions have strongly suggested a similarity between the apparatuses of Hindeodus and other ozarkodinids, the natural assemblages described by Agematsu et al. (2015) were insufficient to determine whether the $\mathrm{S}_{1}$ element was present. In this study, $\mathrm{SR}-\mu \mathrm{CT}$ images of $H$. parvus specimens show that the element composition is consistent with the multielement definition of this genus given by Sweet (1977) and that the 15-element plan is quite similar to a well-known ozarkodinid model. These data will be useful for future studies of the classification and phylogeny of Hindeodus.

\section{Accessibility of supplemental data}

Data available from the Dryad Digital Repository: http://dx.doi. org/10.5061/dryad.488rt

\section{Acknowledgments}

We express sincere thanks to M.J. Orchard for his useful suggestions and comments. The synchrotron radiation experiments were performed at the BL20B2 of SPring-8 with the approval of the Japan Synchrotron Radiation Research Institute (JASRI) (Proposal No. 2014B1442).

\section{References}

Agematsu, S., Sano, H., and Sashida, K., 2015, Natural assemblages of Hindeodus conodonts from a Permian-Triassic boundary sequence, Japan: Palaeontology, v. 57, p. 1277-1289.

Baesemann, J.F., 1973, Missourian (Upper Pennsylvanian) conodonts of northeastern Kansas: Journal of Paleontology, v. 47, p. 689-710.

Bassler, R.S., 1925, Classification and stratigraphic use of conodonts: Geological Society of America Bulletin, v. 36, p. 218-220.

Donoghue, P.C.J., Purnell, M.A., Aldridge, R.J., and Zhang, S., 2008, The interrelationships of 'complex' conodonts (Vertebrata): Journal of Systematic Palaeontology, v. 6, p. 119-153.

Dzik, J., 1976, Remarks on the evolution of Ordovician conodonts: Acta Palaeontologica Polonica, v. 21, p. 395-455.

Dzik, J., 1991, Evolution of oral apparatuses in the conodont chordates: Acta Palaeontologica Polonica, v. 36, p. 265-323.
Ellison, S.P., 1941, Revision of the Pennsylvanyan conodonts: Journal of Paleontology, v. 15, p. 107-143.

Goto, S., Takeshita, K., Suzuki, Y., Ohashi, H., Asano, Y., Kimura, H., Matsushita, T., Yagi, N., Isshiki, M., Yamazaki, H., Yoneda, Y., Umetani, K., and Ishikawa, T., 2001, Construction and commissioning of a 215-m-long beamline at SPring-8: Nuclear Instruments and Methods in Physics Research, A467-468, p. 682-685.

Hinde, G.J., 1900, Notes and descriptions of new species of Scotch Carboniferous conodonts: Transactions of the Natural History Society of Glasgow, v. 5, n. ser., pt. 3, p. 338-346.

Jeppsson, L., 1971, Element arrangement in conodont apparatuses of Hindeodella type and in similar forms: Lethaia, v. 4, p. 101-123.

Kozur, H., 1975, Beiträge zur Conodontenfauna des Perm: Geologisch-paläontologische Mitteilungen Innsbruck, v. 5, p. 1-41.

Kozur, H., 1989, Significance of events in conodont evolution for the Permian and Triassic stratigraphy: Courier Forschungsinstitut Senckenberg, v. 117, p. 409-469.

Kozur, H., 1995, Some remarks to the conodonts Hindeodus and Isarcicella in the latest Permian and earliest Triassic: Palaeoworld, v. 6, p. 64-77.

Kozur, H., 1996, The conodonts Hindeodus, Isarcicella and Sweetohindeodus in the uppermost Permian and lowermost Triassic: Geologia Croatia, v. 49, p. 81-115.

Kozur, H., and Pjatakova, M., 1976, Die Conodontenart Anchignathodus parvus n. sp., eine wichtige Leiform der basalen Trias: Proceedings of the Koninklijke Nederlandese Akademie van Wetenschappen, Series B, v. 79 p. $123-128$.

Kozur, H., Mostler, H., and Rahimi-Yazd, A., 1975, Beiträge zur Mikropaläontologie permotriadischer Schichtfolgen. Teil II: Neue Conodonten aus dem Oberperm und der basalen Trias von Nord- und Zentraliran: Geologisch-Paläontologische Mitteilungen Innsbruck, v. 5, p. 1-23.

Kozur, H., Ramovš, A., Wang, C., and Zakharov, Y.D., 1995, The importance of Hindeodus parvus (Conodonta) for the definition of the Permian-Triassic boundary and evaluation of the proposed sections for a global stratotype section and point (GSSP) for the base of the Triassic: Geologija, v. 37/38, p. 173-213.

Lai, X.L., Yang., F.Q., Hallam, A., and Wignall, P.B., 1996, The Shangsi section, candidate of the global stratotype section and point of the PermianTriassic boundary, in Yin, H.F., ed., The Palaeozoic-Mesozoic boundary, candidates of the global stratotype section and point of the Permian-Triassic boundary: Wuhan, China, China University Geoscience Press, p. 113-124.

Limaye, A., 2012, Drishti, a volume exploration and presentation tool: Proceedings of SPIE, v. 8506, Developments in X-Ray Tomography VIII, 85060X (October 17, 2012). doi: 10.1117/12.935640. http://dx.doi.org/ $10.1117 / 12.935640$

Matsuda, T., 1981, Early Triassic conodonts from Kashmir, India: Journal of Geosciences, Osaka City University, v. 24, p. 75-108.

Nicoll, R.S., Metcalfe, I., and Wang, C., 2002, New species of the conodont genus Hindeodus and the conodont biostratigraphy of the Permian-Triassic boundary interval: Journal of Asian Earth Sciences, v. 20, p. 609-631.

Paganin, D., Mayo, S.C., Gureyev, T.E., Miller, P.R., and Wilkins, S.W., 2002 Simultaneous phase and amplitude extraction from a single defocused image of a homogeneous object: Journal of Microscopy, v. 206, p. 33-40.

Purnell, M.A., and Donoghue, P.C.J., 1997, Architecture and functional morphology of the skeletal apparatus of ozarkodinid conodonts: Philosophical Transactions of the Royal Society of London B, Biological Sciences, v. 352 p. $1545-1564$.

Purnell, M.A., Donoghue, P.C.J., and Aldridge, R.J., 2000, Orientation and anatomical notation in conodonts: Journal of Paleontology, v. 74 p. $113-122$

Rexroad, C.B., 1957, Conodonts from the Chester Series in the type area of southwestern Illinois: Illinois State Geological Survey Report of Investigations 199, $43 \mathrm{p}$.

Rexroad, C.B., and Furnish, W.M., 1964, Conodonts from the Pella Formation (Mississippian), south-central Iowa: Journal of Paleontology, v. 38, p. 667-676.

Sano, H., Kuwahara, K., Yao, A., and Agematsu, S., 2010, Panthalassan seamount-associated Permian-Triassic boundary siliceous rocks, Mino terrane, central Japan: Paleontological Research, v. 14, p. 293-314.

Sweet, W.C., 1970a, Permian and Triassic conodonts from a section at Guryul Ravine, Vihi District: Kashmir, University of Kansas Paleontological Contributions, Paper 49, 10 p.

Sweet, W.C., 1970b, Uppermost Permian and Lower Triassic conodonts of the Salt Range and Trans-Indus Ranges, West Pakistan, in Kummel, B., and Teichert, C., eds., Stratigraphic Boundary Problems: Permian and Triassic of West Pakistan, University of Kansas, Department of Geology, Special Publication, v. 4, p. 207-275.

Sweet, W.C., 1977, Genus Hindeodus, in Ziegler, W., ed., Catalogue of Conodonts III: Stuttgart, Germany, E. Schweitzerbart'sche Verlagsbuchhandlung, p. 203-224. 
Sweet, W.C., 1988, The Conodonta: Morphology, Taxonomy, Palaeoeclogy, and Evolutionary History of a Long-extinct Animal Phylum: Oxford, England, Clarendon Press, 212 p.

Teichert, C., Kummel, B., and Sweet, W.C., 1973, Permian-Triassic strata, KuhE-Ali Bashi, northwestern Iran: Bulletin of the Museum of Comparative Zoology, v. 145 , p. 359-472.

Uesugi, K., Hoshino, M., Takeuchi, A., Suzuki, Y., Yagi, N., and Nakano, T., 2010, Development of fast (sub-minute) micro-tomography: AIP Conference Proceedings, v. 1266, p. 47-50. doi: 10.1063/1.3478197.

von Bitter, P.H., 1972, Environmental control of conodont distribution in the Shawnee Group (Upper Pennsylvanian) of eastern Kansas: The University of Kansas Paleontological Contributions, v. 59, 105 p.

von Bitter, P.H., and Merrill, G.K., 1985, Hindeodus, Diplognathodus, and Elisonia revisited, an identity crisis in Permian conodonts: Geologica et Palaeontologica, v. 19, p. 81-96.

von Bitter, P.H., and Plint, H.A., 1987, Conodonts of the Windsor Group (Lower Carboniferous), Megdalen Islands, Quebec, Canada: Journal of Paleontology, v. 61, p. 346-362. von Bitter, P.H., and Plint-Geberl, H.A., 1982, Conodont biostratigraphy of the Codroy Group (Lower Carboniferous), southwestern Newfoundland, Canada: Canadian Journal of Earth Science, v. 19, p. $193-221$

Walliser, O.H., 1964, Conodonten des Silurs: Abhandlungen des hessischen Landesamtes für Bodenforschung, Wiesbaden, v. 41, p. 1-106.

Wang, C., 1995, Conodonts of the Permian-Triassic boundary beds and biostratigraphic boundary: Acta Palaeontologica Sinica, v. 34, p. $129-151$.

Webers, G.F., 1966, The Middle and Upper Ordovician conodont faunas of Minnesota: Minnesota Geological Survey, Special Publication Series. v. SP-4, p. $1-123$.

Youngquist, W.L., and Miller, A.K., 1949, Conodonts from the Late Mississippian Pella beds of south-central Iowa: Journal of Paleontology, v. 23 , p. $617-622$.

Accepted 7 June 2017 